\title{
Treatment of Early Developed Peri-Implantitis in Fibula Graft Site
}

\section{Liječenje ranoga periimplantitisa u presatku fibule}

\author{
${ }^{1}$ Department of Oral Implantology, Military Medical Academy, University of Defense, Belgrade, Serbia \\ Odjel za oralnu implantologiju, Vojnomedicinska akademija, Sveučilište obrane, Beograd, Srbija \\ 2 Department of Dentistry, Faculty of Medicine, University of Nis, Serbia \\ Zavod za stomatologiju, Medicinski fakultet, Sveučilište u Nišu, Srbija \\ ${ }^{3}$ Department of Maxillofacial surgery, Faculty of Dentistry, University of Belgrade, Serbia \\ Klinika za maksilofacijalnu kirurgiju, Stomatološki fakultet, Sveučilište u Beogradu, Srbija
}

\section{Abstract}

The fibula microvascular free flap technique and placement of dental endosseous implants seem to be viable options for reconstructing the mandible, following a resective jaw surgery. The causes of early failures of implants include bone overheating, latent infection by surgical trauma, the factors related with the implant, and overcompression. This case report reviews the mechanisms of early postimplantation bone loss, and suggests the course of treatment for early peri-implantitis for implants that show no mobility. Radiographs and clinical data presented have shown that the surgical treatment of early developed peri-implantitis using GBR methods in free fibula graft sites offers promising and stabile results.
Received: November 26, 2020

Accepted: February 9, 2021

Address for correspondence

Nenad Petrović

Oral Surgery Resident

Hajduk Stanka St., No. 5 A

18000 Niš, Serbia

Phone: +381643223231

knele987@gmail.com

MeSH terms: Peri-Implantitis; Endosseous Dental Implantation; Surgical Flaps; Microvascular Decompression Surgery; Fibula

Author keywords: Free fibula graft; Implant; Peri-implantitis; Surgical trauma; GBR; Overcompression

\section{Introduction}

In the past 25 years, the fibular microvascular free flap technique has become a routine procedure for the reconstruction of the mandible, in order to correct defects of the bone caused by the resection of the tumor. The literature data show that bone grafting and placement of dental endosseous implants seem to be widely accepted treatment options for reconstructing the mandible, following resective jaw surgery (1).

Long-term studies show that the survival rate of implants placed into the fibula is acceptable (2).

Early failures of implants are defined as those occurring between first and second-stage surgery, and the causes include bone overheating, latent infection by surgical trauma, the factors related with the implant, and overcompression $(3,4)$. The early peri-implant changes, apparent on the $\mathrm{x}$ rays around the implants that have not yet been loaded, suggest iatrogenic causes of rapid crestal bone resorption, due to various factors, such as pour indication, extremely hard and poorly vascularized bone, surgical trauma, lack of keratinized gingiva (5).

The authors of this paper suggest that the course of treatment for these peri-implant early changes and bone necrosis
Uvod

U posljednjih 25 godina tehnika fibularnoga mikrovaskularnog režnja postala je rutinski postupak u rekonstrukciji donje čeljusti kako bi se ispravili koštani defekti prouzročeni resekcijom tumora. Podatci iz literature pokazuju da su koštani presatci i postavljanje zubnih endoosealnih implantata široko prihvaćene mogućnosti liječenja u rekonstrukciji donje čeljusti nakon resekcije (1).

Dugotrajna ispitivanja pokazuju da je stopa trajnosti implantata ugrađenih u fibulu prihvatljiva (2).

Rani neuspjesi pri ugradnji implantata definiraju se kao oni koji se pojavljuju između prve i druge kirurške faze, a uzroci uključuju pregrijavanje kosti, latentnu infekciju prouzročenu kirurškom traumom, čimbenike povezane s implantatom i prejaku kompresiju $(3,4)$. Rane periimplantatne promjene, vidljive na radiološkim snimkama implantata koji još nisu opterećeni, sugeriraju jatrogene uzroke brze resorpcije krestalne kosti zbog različitih čimbenika, kao što su nepravilna indikacija, iznimno tvrda i slabo vaskularizirana kost, kirurška trauma i nedostatak keratinizirane gingive (5).

Autori ovoga rada sugeriraju da tijek liječenja ranih periimplantatnih promjena i nekroze kosti oko implantata koji 
around implants that show no mobility, even in the free fibula graft site, can be the guided bone regeneration protocol, with prior surgical debridement of granulation tissue and detailed cleaning of the implant surface.

It is now accepted that clinicians can try to regenerate the bone that was resorbed as a result of infection, following successful decontamination of the implant surface and bone defect. With the re-osseointegration as the ultimate goal, a number of regenerative techniques have been introduced, and various success rates in the use of regenerative procedures have been reported, regardless of radiographic evidence of defect fill (6).

As with treatment of peri-implantitis, the primary objective is the elimination of the biofilm from the implant surface, utilizing one of the various protocols suggested that include the use of antiseptics, antibiotics, air-abrasive devices and lasers (7). The use of laser for decontamination in surgical resective or regenerative therapies may lead to better clinical results than conventional treatment alone (8).

The aim of this paper was to present the management of early developed peri-implantitis in fibula graft site by utilizing surgical protocol for guided bone regeneration and laser-assisted surgical debridement and implant surface sterilization.

\section{Clinical presentation}

\section{Pre-implantation clinical findings}

A 26-year-old male patient presented to the Department of Implantology, Clinic of Dentistry, following the resection of the right side of the mandible, and reconstruction with the fibular microvascular graft. The patient was referred to this department from the Clinic of Maxillofacial surgery, for the purpose of receiving dental implants in the fibular graft area, and complete prosthetic rehabilitation to replace the missing teeth and the supporting alveolus.

Discharge summary from the Clinic of Maxillofacial Surgery contained following information:

- The need for mandibular resection was the recidivism of previously pathohistologically proven myxoma.

- The course of maxillofacial treatment: First surgery: Resection of the right-side body and angle of the mandible, reconstruction of the defect with the fibular microvascular autotransplant, fixation of the fragments with mini plates, and rigid intermaxillary immobilization; Second surgery: A day later, due to the development of hematoma in the early postoperative period, revision and hematoma evacuation surgery with anastomosis revision was performed. The patient was treated with antibiotics, wound debridement was done regularly, and the patient was fed through the nasogastric tube; Third surgery: Eight days following the second surgery, a dehiscence of the intraoral wound was noticed, and a revision of the wound was performed; Fourth surgery: Due to the prominence of the part of the bone transplant, a wound revision with osteotomy of the part of the autotransplant was performed, 20 days after the last procedure.

- The postoperative course was uneventful, with the ad- ne pokazuju pomičnost čak ni u slobodnom presatku fibule, može biti protokol vođene regeneracije kosti, uz prethodno kirurško uklanjanje granulacijskoga tkiva i temeljito čišćenje površine implantata.

Sada je prihvaćeno da kliničari mogu pokušati obnoviti kost koja je resorbirana kao posljedica infekcije nakon uspješne dekontaminacije površine implantata i koštanoga defekta. $S$ reoseointegracijom kao konačnim ciljem, uvedeni su mnogobrojni postupci za regeneraciju i zabilježeni su različiti stupnjevi uspješnosti u njihovoj primjeni, bez obzira na radiografske dokaze o ispunjenosti defekta (6).

Kao i pri liječenju periimplantitisa, primarni cilj je uklanjanje biofilma s površine implantata koristeći se jednim od različitih predloženih protokola koji uključuju upotrebu antiseptika, antibiotika, zračno-abrazivnih uređaja i lasera (7). Upotreba lasera za dekontaminaciju u kirurškim resektivim ili regenerativnim terapijama može rezultirati boljim kliničkim rezultatom negoli u slučaju konvencionalnog liječenja (8).

Svrha ovoga rada bila je opisati postupak $s$ ranim periimplantitisom u presatku fibule primjenom kirurškoga protokola za vođenu regeneraciju kosti i laserski potpomognutog kirurškog debridmana i sterilizacije površine implantata.

\section{Klinički prikaz}

\section{Klinički nalazi prije implantacije}

Pacijent u dobi od 26 godina došao je u Odjel za implantologiju Stomatološke klinike nakon resekcije desne strane donje čeljusti i rekonstrukcije fibularnim mikrovaskularnim presatkom. Uputili su ga liječnici iz Klinike za maksilofacijalnu kirurgiju radi ugradnje zubnih implantata u područje fibularnoga presatka i potpune protetičke rehabilitacije radi nadomještanja nedostajućih zuba i potporne alveole.

Sažetak njegova otpusnoga pisma sadržavao je sljedeće podatke:

- resekcija donje čeljusti bila je učinjena zbog recidiva patohistološki dokazanog miksoma

- tijek maksilofacijalnog liječenja: prva operacija - resekcija desne strane tijela i kuta donje čeljusti, rekonstrukcija defekta fibularnim mikrovaskularnim autotransplantatom, fiksiranje fragmenata minipločicama i kruta intermaksilarna imobilizacija; druga operacija - obavljena je dan poslije prve zbog pojave hematoma u ranom postoperativnom razdoblju te je izvađen hematom uz reviziju anastomoze; pacijent je liječen antibioticima, redovito se čistila rana i hranio se s pomoću nazogastrične sonde; treća operacija - učinjena je osam dana nakon druge jer je uočena dehiscencija intraoralne rane pa je učinjena revizija rane; četvrta operacija - učinjena je 20 dana nakon posljednjeg postupka, obavljena je zbog prominencije dijela transplantirane kosti, a učinjena je revizija rane $s$ osteotomijom dijela autotransplantata.

Postoperativni tijek bio je bez poteškoća, uz davanje antibiotika i redovito čišcenje rane. Rana je zarastala per primam, a nakon uklanjanja fiksacije opseg kretanja mandibule bio je u fiziološkim granicama. 
ministration of antibiotics and regular wound debridement. The wound healed per primam, and after the removal of the intramaxillary fixation, the range of mandibular movement was within physiological boundaries.

\section{Implantation procedure}

Anamnestic data showed no medical history of systemic or metabolic diseases, and the patient did not receive any kind of drug therapy at the time. After a detailed clinical and radiographic examination, the patient was scheduled for implant surgery, one year following the fibular graft transplantation.

The course of surgery: The procedure was performed in local anesthesia. After the elevation of the mucoperiosteal flap, which proved to be difficult due to the abundance of scar tissue, the bone sockets in the fibular graft site were prepared, and three Nobel Replace $4,3 \times 10 \mathrm{~mm}$ implants were placed in the region of teeth 43,45 and 46 . At that time, the bone density was assessed as D1, with very low blood supply. Healing abutments were placed on the implants, and the wound was sutured around them (Figure 1a). The wound healed partially per secundam intentionem.

\section{Post-implantation clinical findings}

Two weeks after the implantation, delayed healing, mild gingival inflammation and bleeding on probing was observed around two distal implants, without any major subjective symptoms reported by the patient. No mobility of the implants was noted.

Due to anatomical limitations in post-reconstructive surgery (high floor of the mouth), retroalveolar radiographs could not be obtained, hence the panoramic radiographs were used to assess peri-implant bone resorption, as has been described by Gbara et al. in 2007 (9).

Marginal bone radiolucency in the two distal implants region was observed on the panoramic x-ray, suggesting bone necrosis due to surgical trauma (Figure 1b).

\section{Course of treatment and outcome}

Nonsurgical treatment was implemented: rinsing with saline and local drug application (Volon A Haftsalbe ung). Despite the treatments, the resorption of bone seemed to be more pronounced on the panoramic x-ray at two-month post-implantation follow-up; therefore, the decision was made to treat those peri-implant changes with regenerative surgical technique (Figure 1c).

Upon application of a local anesthetic solution (Ubistesin forte $1: 100000$ ) in implanted regions (infiltration anesthesia), the mucoperiosteal flap was elevated and a cratershaped bone resorption was observed around the two distal implants, as well as the granulation tissue filling the defects (Figure 2a). The Bio-lase Water-lase Express laser was used to remove granulations. A granulation removal mode was applied, according to the manufacturer's instructions. The mode was then changed and the implant surface was disinfected (Figure 2b). The cleaned surfaces were washed with saline, and a bone substitute Bio-oss, along with collagen membrane Bio-gide were applied, in a guided bone regeneration attempt (Figure 3a and 3b). The surgical site was closed with

\section{Postupak implantacije}

Anamnestički podatci nisu pokazali medicinsku povijest sistemskih ili metaboličkih bolesti, a pacijent u tom razdoblju nije imao nikakvu terapiju lijekovima. Nakon detaljnoga kliničkoga i radiografskoga pregleda dogovorena je implantacija, godinu dana nakon transplantacije fibularnoga presatka.

Tijek operacije: postupak je obavljen u lokalnoj anesteziji; nakon što je podignut mukoperiostalni režanj, što se pokazalo zahtjevnim zbog obilja ožiljnoga tkiva, pripremljena su ležišta za implantate u fibularnom presatku te su u područje zuba 43, 45 i 46 postavljena tri implantata Nobel Replace 4,3 x $10 \mathrm{~mm}$. Tada je gustoća kosti procijenjena kao D1, $s$ vrlo niskom opskrbom krvlju. $\mathrm{Na}$ implantate su postavljene nadogradnje za cijeljenje, a rana oko njih je sašivena (slika 1a). Rana je zarasla djelomično per secundam intentionem.

\section{Klinički nalazi nakon implantacije}

Dva tjedna nakon implantacije uočeno je odgođeno zacjeljivanje, blaga upala gingive i krvarenje pri sondiranju oko dvaju distalnih implantata, bez ikakvih većih subjektivnih simptoma. Nije primijećena pomičnost implantata.

Zbog anatomskih ograničenja u postrekonstrukcijskoj kirurgiji (uzdignuto dno usne šupljine), nije se mogla učiniti retroalveolarna radiološka snimka pa su za procjenu periimplantne resorpcije kosti učinjene panoramske snimke, kao što su opisali Gbara i sur. 2007. godine (9).

Marginalno prosvjetljenje kosti u području dvaju distalnih implantata uočena je na panoramskoj snimci, što upućuje na nekrozu kosti zbog kirurške traume (slika 1b).

\section{Tijek liječenja i ishod}

Primijenjeno je nekirurško liječenje - ispiranje fiziološkom otopinom i lokalna primjena lijeka (Volon A Haftsalbe ung). Unatoč tretmanima činilo se da je resorpcija kosti bila izraženija na panoramskoj snimci učinjenoj dva mjeseca nakon implantacije. Zato je odlučeno da se te perimplantne promjene liječe regenerativnom kirurškom tehnikom (slika 1c).

Nakon lokalne anestezije (Ubistesin forte 1 : 100.000) u implantirana područja (infiltracijska anestezija), odignut je mukoperiostalni režanj i uočena je resorpcija kosti u obliku kratera oko dvaju distalnih implantata te granulacijsko tkivo koje ispunjava defekt (slika 2a). Za uklanjanje granulacija korišten je biolaser Water-lase Express. Primijenjen je mod za uklanjanje granulacija prema uputama proizvođača. Nakon toga je promijenjen mod i površina implantata je dezinficirana (slika 2b). Očišćene površine isprane su fiziološkom otopinom i u vođenoj regeneraciji kosti postavljen je nadomjestak za kost Bio-oss, zajedno s kolagenskom membranom Bio-gide, (slike 3a i 3b). Kirurško mjesto zatvoreno je pojedinačnim šavovima. Propisana je sistemska antibiotska terapija 

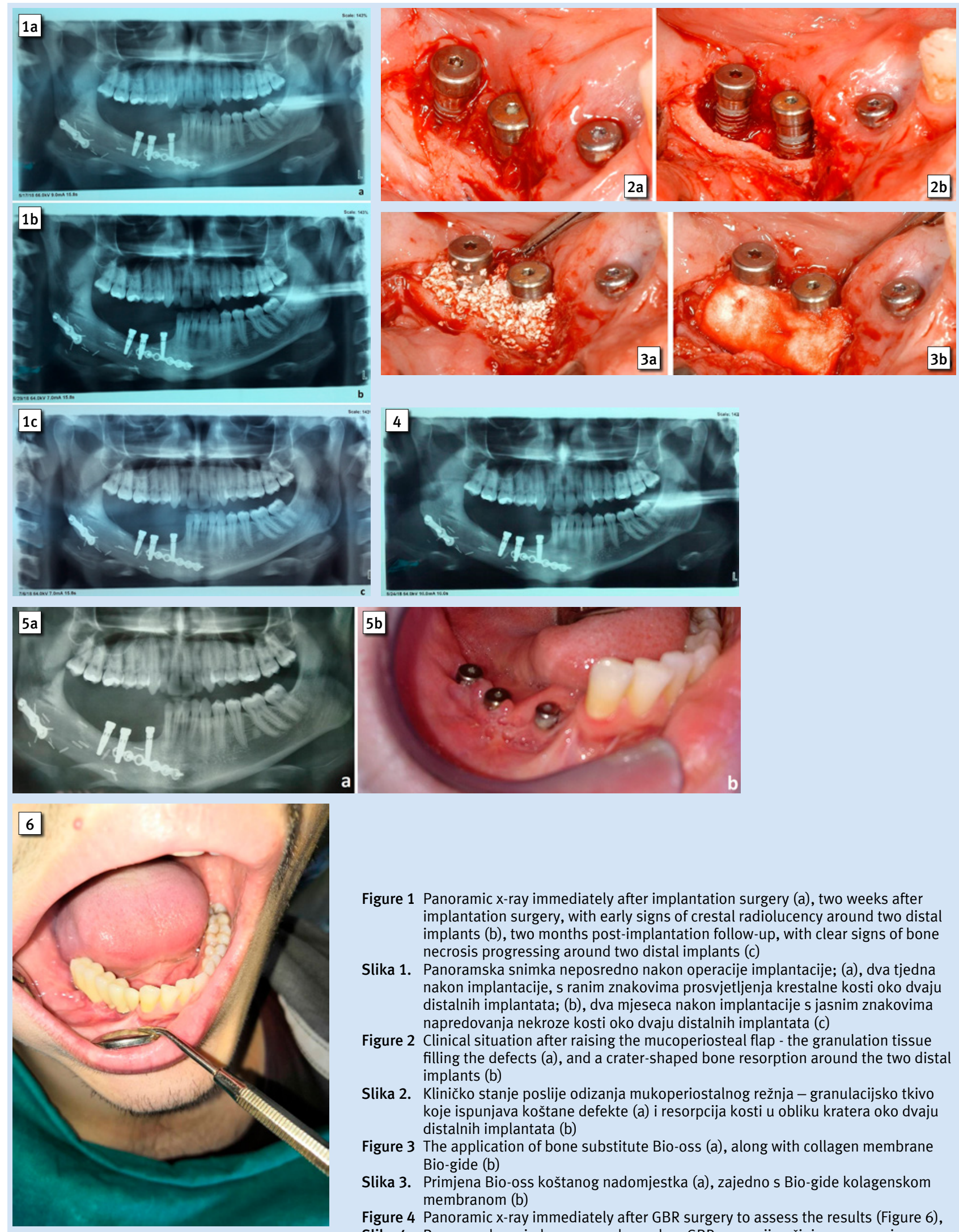

Figure 1 Panoramic x-ray immediately after implantation surgery (a), two weeks after implantation surgery, with early signs of crestal radiolucency around two distal implants (b), two months post-implantation follow-up, with clear signs of bone necrosis progressing around two distal implants (c)

Slika 1. Panoramska snimka neposredno nakon operacije implantacije; (a), dva tjedna nakon implantacije, s ranim znakovima prosvjetljenja krestalne kosti oko dvaju distalnih implantata; (b), dva mjeseca nakon implantacije s jasnim znakovima napredovanja nekroze kosti oko dvaju distalnih implantata (c)

Figure 2 Clinical situation after raising the mucoperiosteal flap - the granulation tissue filling the defects (a), and a crater-shaped bone resorption around the two distal implants (b)

Slika 2. Kliničko stanje poslije odizanja mukoperiostalnog režnja - granulacijsko tkivo koje ispunjava koštane defekte (a) i resorpcija kosti u obliku kratera oko dvaju distalnih implantata (b)

Figure 3 The application of bone substitute Bio-oss (a), along with collagen membrane Bio-gide (b)

Slika 3. Primjena Bio-oss koštanog nadomjestka (a), zajedno s Bio-gide kolagenskom membranom (b)

Figure 4 Panoramic x-ray immediately after GBR surgery to assess the results (Figure 6),

Slika 4. Panoramska snimka neposredno nakon GBR operacije učinjena za procjenu rezultata (slika 6.)

Figure 5 Panoramic x-ray (a) and intraoral status (b) at four months follow-up - the radiolucencies resolved entirely.

Slika 5. Panoramska snimka (a) i intraoralni status (b) nakon četveromjesečnoga praćenja - prosvjetljenja su potpuno nestala

Figure 6 The implants loaded with a lateral metal-ceramic bridge - intraoral view Slika 6. Implantati opterećeni bočnim metal-keramičkim mostom - intraoralni pogled 
single interrupted sutures. Systemic antibiotic therapy was prescribed (caps. Amoxicillin, 500mg/8h). A panoramic xray was made immediately after surgery to assess the results (Figure 4), as well as at four months follow-up (Figure 5a and 5b). The radiolucencies resolved entirely. Four months after surgery, the implants were loaded with a lateral metal-ceramic bridge (Figure 6).

\section{Discussion}

As for etiologies suggested in regard to early implant failure, surgical trauma has been stated among the most common factors. Implant failures due to this factor show early radiographical signs of a crater-shaped crestal bone defect, and are surrounded by granulation and fibrous connective tissue (5).

Thermally-induced bone necrosis and overcompression are the most probable causes of early implant failure, due to the necrosis of the surrounding differentiated and undifferentiated cells, leading to the failure of bone integration $(3,4)$.

Compression of bone beyond its physiologic tolerance and excessive torque placed on an implant may result in high levels of strain transmitted to the adjacent bone and ischemia with subsequent necrosis, especially in the crestal region of an implant, which is often composed of dense cortical bone with a minimal blood supply (3).

Although early crestal bone loss may produce the environment that is favorable for anaerobic bacterial growth, especially in one phase implant placement technique as in this case, and thus possibly contribute to more bone destruction in following years, there has been no evidence in the literature that peri-implantitis induces crestal bone loss during the healing period and the first year after prosthetic loading at a faster rate than in the years to follow $(10,11)$.

On the other hand, Sakka\& Colthard stated that infection is the most common explanation for complications that might occur during the healing period and may, as in the case presented here, include signs such as early mucosal dehiscence that can impair the bone healing process which leads to the integration of the implant (12).

Pellegrino et al. showed a satisfactory long-term survival rate of implants placed into the fibula graft site, but they pointed out the problems of peri-implant bone resorption over time, that is mainly related to peri-implant gingival mucositis, due to the soft tissue quality. The authors suggest that skin or connective tissue grafts in planed implant sites, 2-3 months before implantation procedure, seem to offer an aid to manage this problem (2).

Bashutski et al. reported a case in which first signs of radiolucency around implants were apparent one week after implantation, and can clearly be seen 3 weeks post-op, with an apparent delayed healing of the wound, but without clinical signs of infection and no signs of improvement after administration of systemic antibiotic therapy. Histological verification showed aseptic necrosis, with no bacterial infiltration. Some authors believed that overcompression was the most probable cause of the peri-implant necrosis (3).

In our case, there were also no clinical signs of infection,
(Amoksicilin, $500 \mathrm{mg} / 3 \mathrm{x}$ dan). Panoramske snimke učinjene su neposredno poslije kirurškoga zahvata radi procjene rezultata (slika 4) i zatim nakon četveromjesečnoga praćenja (slike 5a i 5b). Prosvjetljenje je potpuno nestalo. Cetiri mjeseca poslije operacije implantati su opterećeni bočnim metalno-keramičkim mostom (slika 6.).

\section{Rasprava}

Kad je riječ o etiologijama predloženima u vezi s ranim neuspješnim postavljanjem implantata, među najčešćcim čimbenicima navedena je kirurška trauma. Neuspjesi pri ugradnji implantata zbog toga čimbenika pokazuju rane radiografske znakove oštećenja kosti u obliku kratera, a okruženi su granulacijama i fibroznim vezivnim tkivom (5).

Termički inducirana nekroza kosti i prejaka kompresija najvjerojatniji su uzroci za rani neuspjeh implantata zbog nekroze okolnih diferenciranih i nediferenciranih stanica, što završava neuspješnom integracijom kosti $(3,4)$.

Kompresija kosti koja prelazi njezinu fiziološku toleranciju i prekomjerna zakretna sila na implantatu mogu rezultirati visokom razinom naprezanja što se prenosi na susjednu kost $\mathrm{i}$ ishemijom s naknadnom nekrozom, posebno u krestalnom dijelu implantata, a koji je često građen od guste kortikalne kosti i minimalno je opskrbljen krvlju (3).

Iako rani gubitak krestalne kosti može stvoriti okružje koje je povoljno za anaerobni rast bakterija, posebno u jednofaznoj tehnici ugradnje implantata kao u ovom slučaju, i na taj način možda pridonijeti većem uništavanju kosti u sljedećim godinama. U literaturi nema dokaza da periimplantitis brže potiče gubitak kosti u razdoblju zacjeljivanja i tijekom prve godine nakon protetičkog opterećenja nego u godinama koje slijede $(10,11)$.

$S$ druge strane, Sakka i Colthard izjavili su da je infekcija najčešce objašnjenje za komplikacije koje bi se mogle dogoditi u razdoblju zacjeljivanja i mogu, kao u opisanom slučaju, uključivati znakove poput rane dehiscencije sluznice koja može smanjiti proces zacjeljivanja kosti koji dovodi do integracije implantata (12).

Pellegrino i sur. pokazali su zadovoljavajuću stopu dugotrajnog preživljavanja implantata u presatku fibule, ali su upozorili i na probleme s periimplantantnom koštanom resorpcijom tijekom vremena koji su uglavnom povezani s periimplantnim gingivalnim mukozitisom zbog kvalitete mekoga tkiva. Autori sugeriraju da cijeljenje kože ili vezivnoga tkiva na planiranim mjestima implantacije od 2 do 3 mjeseca prije postupka implantacije može pomoći u rješavanju toga problema (2).

Bashutski i sur. izvijestili su o slučaju u kojemu su prvi znakovi prosvjetljenja oko implantata bili vidljivi tjedan dana nakon implantacije, a jasno su se uočavali 3 tjedna nakon operacije, $s$ prividnim odgođenim zacjeljivanjem rane, ali bez kliničkih simptoma infekcije i bez znakova poboljšanja poslije primjene sistemske antibiotske terapije. Histološka verifikacija pokazala je aseptičnu nekrozu bez bakterijske infiltracije. Neki autori pretpostavljaju da je prejaka kompresija najvjerojatniji uzrok periimplantne nekroze (3). 
only a delayed per sec healing. Considering the specificity of the case itself, the fact that there was no mobility in the implants, and also that the removal of the implants in this phase would probably lead to major defects in the grafted fibula site and the inability for implant placement without additional grafting, the decision was made to implement a protocol for laser-assisted surgical debridement and implant surface sterilization, followed by a guided bone regeneration procedure.

The decision on surgical technique (resective or regenerative) to treat peri-implantitis-like changes depends on the clinical situation. Even if surgery seems to be the therapy of choice, nonsurgical therapy should always be performed before surgical interventions (7).

If a crater-shaped lesion is present around the infected implant, regenerative techniques are needed. A number of different grafting materials, with or without use of a membrane, or the use of membranes alone, have been proposed over the years, in an attempt to regenerate the lost bone and induce re-osseointegration on the previously contaminated implant surface (13).

In a randomized clinical trial Renvert et al. compared augmented sites, with surface debridement and decontamination alone, and concluded that the successful treatment outcome using a bone substitute was more predictable (14).

In 2019, Di Carlo et al. reported a GBR procedure performed in the post graft site, in which the onset of peri-implantitis led to the failure of osseointegration with consequent thinning of the fibula flap (15).

Following mechanical decontamination, chlorhexidine, citric acid, tetracycline, hydrochloric acid, chloramines, hydrogen peroxide or sodium chloride were used for the purpose of chemical decontamination, and, no agents have yet been shown to be superior (12).

Some authors have suggested that decontamination and detoxification of implant surfaces cannot be achieved using hand curettes in narrow bony defects. Also, the infracrestal application of air-powder abrasives may cause embolization, whereas laser application is not associated with such serious risks $(7,14)$.

Laser decontamination of the implant surface as an adjunct to surgical regenerative therapies may lead to better clinical results than conventional treatment alone. Clinical improvements have been reported for both the use of lasers and air-abrasive devices on treatment outcome in the short term and the long term, but the evidence is still weak $(6,16)$.

We have decided to use Bio-lase Water-lase Express laser for granulation removal and implant surface disinfection.

In the study of Serino \& Turri, the authors concluded that the amount of initial bone loss around the implants seemed to affect disease resolution, and that disease progressed for the implants which showed the signs of peri-implantitis following the therapy (17).

In the case presented here, the bone levels seemed to be stable 6 months following the GBR procedure, suggesting that surgical treatment of early developed peri-implantitis using GBR methods in free fibula graft sites shows promising and stable results. Further exploration of this specific type of cases, with years of follow-up, is needed in order to set
U našem slučaju također nije bilo kliničkih znakova infekcije, nego samo odgođeno per secundam zacjeljivanje. Uzimajući u obzir specifičnost slučaja, činjenicu da nije bilo pomičnosti implantata te da bi uklanjanje implantata u toj fazi vjerojatno završilo nastankom većih defekata u presatku fibule i nemogućnosti za ugradnju implantata bez dodatnoga presatka, odlučeno je da se primijeni protokol za laserski potpomognutim kirurškim debridmanu i sterilizaciji površine implantata, nakon čega slijedi postupak vođene regeneracije kosti.

Odluka o kirurškoj tehnici (resekcijskoj ili regenerativnoj) za liječenje promjena nalik na periimplantitis ovisi o kliničkoj situaciji. Čak i ako se čini da je operacija terapija izbora, nekirurško liječenje uvijek treba primijeniti prije kirurških intervencija (7).

Ako je oko inficiranog implantata nastala lezija u obliku kratera, potrebne su tehnike za regeneraciju. Tijekom godina predložen je niz različitih materijala za ugrađivanje $s$ upotrebom membrana ili bez njih, ili samo s membranom, u pokušaju regeneracije izgubljene kosti i induciranja reosteointegracije na prije kontaminiranoj površini implantata (13).

$\mathrm{U}$ randomiziranom kliničkom ispitivanju Renvert i sur. usporedili su augmentirana mjesta sa samo površinskim debridmanom i dekontaminacijom te zaključili da je uspješan ishod liječenja predvidiv ako se upotrijebi nadomjestak za kosti (14).

Godine 2019. Di Carlo i sur. izvijestili su o GBR postupku obavljenom na mjestu nakon grafta, u kojemu je pojava periimplantitisa prouzročila neuspjeh oseointegracije s posljedičnim stanjivanjem režnja fibule (15).

Nakon mehaničke dekontaminacije, u svrhu kemijske dekontaminacije, korišteni su klorheksidin, limunska kiselina, tetraciklin, klorovodična kiselina, kloramini, vodikov peroksid ili natrijev klorid, no još nije dokazano da je ijedno od tih sredstava superiorno (12).

Neki autori sugeriraju da se dekontaminacija i detoksikacija površine implantata ne može postići ručnim kiretama u uskim koštanim defektima. Također, infrakrestalna primjena abraziva u zračnom prahu može prouzročiti embolizaciju. Primjena lasera nije povezana s tako teškim rizicima $(7,14)$.

Laserska dekontaminacija površine implantata, kao dodatak kirurškim regenerativnim terapijama, može rezultirati boljim kliničkim rezultatima negoli samo konvencionalno liječenje. Zabilježena su klinička poboljšanja kako pri upotrebi lasera, tako i zračnih abrazivnih uređaja na ishod liječenja kratkoročno i dugoročno, ali dokazi su i dalje nedovoljni $(6,16)$.

Odlučili smo se koristiti biolaserom Bio-lase Water-lase Express za uklanjanje granulacija i dezinfekciju površine implantata.

U istraživanju Serina i Turrija autori su zaključili da količina početnoga gubitka kosti oko implantata može utjecati na rješenje bolesti, te da bolest napreduje ako su implantati nakon terapije pokazivali znakove periimplantitisa (17).

U ovdje opisanom slučaju činilo se da su razine kosti stabilne šest mjeseci poslije GBR postupka, što sugerira da takvo kirurško liječenje ranoga periimplantitisa u presatku fibule pokazuje obećavajuće i stabilne rezultate. Potrebno je 
the therapy guidelines for peri-implantitis in free fibula graft sites.

\section{Conflict of interest}

The authors report no conflict of interest

Author's contribution: Z. T., M. B., N. P. - preformed the implantation procedure; Z. T., V. K. - carried out the guided bone regeneration procedure; R. M. - completed the prosthetic treatment; Z. T., N. P. - drafted the manuscript; M. B., R. M. - revised it critically; V. K. - gave final approval of the version to be submitted. All authors discussed the case and contributed to the final manuscript. daljnje istraživanje te specifične vrste slučajeva da bi se postavile smjernice terapije za periimplantitis u presatku fibule.

\section{Sukob interesa}

Autori nisu bili u sukobu interesa.

Doprinos autora: Z. T., M. B., N. P. - obavili su implantaciju; Z. T., V. K. - proveli su postupak vođene regeneracije kosti; R. M. - završio je protetički tretman; Z. T., N. P. - pripremili su tekst; M. B., R. M. - kritički su revidirali tekst; V. K. - dao je konačno odobrenje za objavljivanje članka. Svi su autori razgovarali o slučaju i dali svoj doprinos konačnoj verziji teksta.

\section{Sažetak}

Čini se da je tehnika mikrovaskularnoga režnja fibule i postavljanje zubnih endoosealnih implantata održiva opcija za rekonstrukciju donje čeljusti nakon resekcije. Uzroci ranih neuspjeha pri ugradnji implantata su pregrijavanje kosti, latentna infekcija izazvana kirurškom traumom, čimbenici povezani s implantatom i prejaka kompresija. Ovaj prikaz slučaja pregled je mehanizama ranoga gubitka kosti nakon implantacije i sugerira tijek liječenja ranoga periimplantitisa za implantate koji nisu pomični. Radiografija i prezentirani klinički podatci pokazali su da kirurško liječenje ranoga periimplantitisa korištenjem vođene koštane regeneracije (GBR) u slobodnom presatku fibule nudi obećavajuće i stabilne rezultate.
Zaprimljen: 26. studenoga 2020. Prihvaćen: 9. veljače 2021.

Adresa za dopisivanje Nenad Petrović, specijalizant oralne kirurgije

Hajduk Stanka, br. 5 A, 18000 Niš, Srbija

telefon: +381643223231

knele987@gmail.com

MeSH pojmovi: periimplantitis; endosealna zubna implantacija; kirurški režnjevi; mikrovaskularna dekompresijska kirurgija; fibula Autorske ključne riječi: slobodni presadak fibule, implantat, periimplantitis, kirurška trauma, GBR, prejaka kompresija

\section{References:}

1. Wang F, Huang W, Zhang C, Sun J, Kaigler D, Wu Y. Comparative analysis of dental implant treatment outcomes following mandibular reconstruction with double-barrel fibula bone grafting or vertical distraction osteogenesis fibula: a retrospective study. Clin Oral Implants Res. 2015 Feb;26(2):157-65.

2. Pellegrino, G, Tarsitano, A, Ferri, A, Corinaldesi, G, Bianchi, A, Marchetti, C. Long term results of osseointegrated implant based dental rehabilitation in oncology patients reconstructed with a fibula free flap. Clin Implant Dent Relat Res. 2018 Oct;20(5):852859.

3. Bashutski JD, D'Silva NJ, Wang H-L. Implant Compression Necrosis: Current Understanding and Case Report. J Periodontol. 2009 Apr;80(4):700-4.

4. Jo K-H, Yoon K-H, Park K-S, Bae J-H, You K-H, Han J-H, et al. Thermally induced bone necrosis during implant surgery: 3 case reports. J Korean Assoc Oral Maxillofac Surg 2011;37:406-414.

5. Esposito M, Hirsch J-M, Lekholm U, Thomsen P. Biological factors contributing to failures of osseointegrated oral implants, (II). Etiopathogenesis. Eur J Oral Sci. 1998 Jun;106(3):721-64.

6. Zitzmann NU, Berglundh T. Definition and prevalence of peri-implant diseases. J Clin Periodontol. 2008 Sep;35(8 Suppl):286-91.

7. Renvert S, Polyzois IN. Clinical approaches to treat peri-implant mucositis and peri-implantitis. Periodontol 2000. 2015 Jun;68(1):369-404.

8. Deppe H, Horch H-H, Neff A. Conventional versus $\mathrm{CO} 2$ laser-assisted treatment of peri-implant defects with the concomitant use of pure-phase beta-tricalcium phosphate: a 5-year clinical report. Int J Oral Maxillofac Implants. Jan-Feb 2007;22(1):79-86.
9. Gbara A, Darwich K, Li L, Schmelzle R, Blake F. Long-Term Results of Jaw Reconstruction With Microsurgical Fibula Grafts and Dental Implants. J Oral Maxillofac Surg 2007;65:1005-1009.

10. Oh T-J, Yoon J, Misch CE, Wang H-L. The Causes of Early Implant Bone Loss: Myth or Science? J Periodontol 2002;73:322-333.

11. Souza CA, Pinho RCM, de Siqueira RAC, de Andrade ALFS, Vajgel BCF, da Silva Neto JC, Cimões R. Factors Influencing the Presence of Papilla between Adjacent Implants and between a Tooth and an Implant. Acta Stomatol Croat. 2019 Dec;53(4):337-346.

12. Sakka S, Coulthard P. Implant failure: Etiology and complications. Med Oral Patol Oral Cir Bucal. 2011 Jan 1;16(1):e42-4.

13. Khoury F, Buchmann R. Surgical Therapy of Peri-Implant Disease: A 3-Year Follow-Up Study of Cases Treated With 3 Different Techniques of Bone Regeneration. J Periodontol 2001;72:1498-1508.

14. Renvert S, Roos-Jansåker A-M, Persson GR. Surgical treatment of peri-implantitis lesions with or without the use of a bone substitute-a randomized clinical trial. J Clin Periodontol. 2018 Oct;45(10):1266-1274.

15. Carlo S Di, Valentini V, Grasso E, Angelis F De, Piccoli L, Quarato A, et al. Implant-Supported Rehabilitation Using GBR Combined with Bone Graft on a Reconstructed Maxilla with the Fibula Free Flap. Case Rep Dent. 2019 Nov 5;2019:2713542.

16. Bach G, Neckel C, Mall C, Krekeler G. Conventional Versus LaserAssisted Therapy of Periimplantitis. Implant Dent. 2000;9(3):24751.

17. Serino G, Turri A. Outcome of surgical treatment of peri-implantitis: results from a 2-year prospective clinical study in humans. Clin Oral Implants Res. 2011 Nov;22(11):1214-20. 